\title{
Influence of electrical properties on the evaluation of the surface hydrophobicity of Bacillus subtilis
}

\author{
François Ahimou ${ }^{\mathrm{a}}$, Michel Paquot ${ }^{\mathrm{a}, *}$, Philippe Jacques ${ }^{\mathrm{b}}$, Philippe Thonart $^{\mathrm{b}}$, \\ Paul G. Rouxhet ${ }^{\mathrm{c}}$ \\ anité de Chimie Biologique Industrielle, Faculté Universitaire des Sciences Agronomiques de Gembloux, Passage des Déportés 2, \\ B-5030 Gembloux, Belgium \\ ${ }^{\mathrm{b}}$ Centre Wallon de Biologie Industrielle, Faculté Universitaire des Sciences Agronomiques de Gembloux, Passage des Déportés 2, \\ B-5030 Gembloux, Belgium \\ ${ }^{c}$ Unité de Chimie des Interfaces, Université Catholique de Louvain, Croix du Sud 2/ 18, B-1348 Louvain-la-Neuve, Belgium
}

Received 25 September 2000; received in revised form 1 December 2000; accepted 15 February 2001

\begin{abstract}
The surface hydrophobicity of nine Bacillus subtilis strains in different states (spores, vegetative cells, and dead cells) was assessed by water contact angle measurements, hydrophobic interaction chromatography (HIC) and bacterial adhesion to hydrocarbon (BATH). Electrokinetic properties of B. subtilis strains were characterized by zeta potential measurements and found to differ appreciably according to the strain. Correlations between HIC data, BATH data and zeta potential showed that HIC and BATH are influenced by electrostatic interactions. Water contact angle measurements thus provide a better estimate of cell surface hydrophobicity. The water contact angle of B. subtilis varied according to the strain and the state, the spores tending to be more hydrophobic than vegetative cells. (C) 2001 Elsevier Science B.V. All rights reserved.
\end{abstract}

Keywords: Bacillus subtilis; Electrical properties; Hydrophobicity

\section{Introduction}

Microbial cell surface hydrophobicity is recognized as one of the determinant factors in microbial adhesion to surfaces (van Loosdrecht et al., 1987a,b). However the measurement of microbial cell surface hydrophobicity remains difficult. Cell aggregation

\footnotetext{
"Corresponding author. Tel.: +32-81-62-22-29; fax: +32-8162-22-31.

E-mail address: chimbioindus@fsagx.ac.be (M. Paquot).
}

upon salt addition and latex particle agglutination (Dillon et al., 1986; Mozes and Rouxhet, 1987; van der Mei et al., 1987) are clearly depending on electrostatic interactions. The same objective holds for adhesion to polystyrene; the surface of polystyrene materials is indeed negatively charged (Dewez et al., 1997).

The microbial cell surface hydrophobicity is often evaluated by hydrophobic interaction chromatography (Stenström, 1989), bacterial adhesion to hydrocarbon (Rosenberg et al., 1980) and water contact angle measurement (Absolom et al., 1983; Busscher 
et al., 1984). These methods have been subject to comparison (Dillon et al., 1986; Mozes and Rouxhet, 1987; van der Mei et al., 1987); the outcomes of various tests correlate only for particular populations of microbial strains and are still subject to questioning (Geertsema-Doornbusch et al., 1993; van der Mei et al., 1995).

In this paper, the hydrophobicity of Bacillus subtilis cells in different states is assessed by water contact angle measurements, hydrophobic interaction chromatography and bacterial adhesion to hydrocarbon. The aim is to study the correlations between the data obtained with the three methods of hydrophobicity evaluation, and to examine, on a statistical basis, whether these three techniques can be influenced by electrical properties. Therefore, electrokinetic properties of the cells are investigated by zeta potential measurements.

The strains of B. subtilis used synthesize lipopeptides, which exhibit antibiotic and surface active properties (Thimon et al., 1992; Asaka and Shoda, 1996; Razafindralambo et al., 1998; Ahimou et al., 2000). It was shown that B. subtilis adhesion was affected by the strain and the physiological state (Paquot et al., 1994; Garry et al., 1995; 1998). Although there are extensive data on hydrophobicity and adhesion of vegetative cells, relatively few studies have examined the surface hydrophobicity of bacterial spores or their adhesion to substrata (Doyle, 1984; Rosenberg et al., 1985; Koshikawa et al., 1989; Husmark and Rönner, 1990; Rönner et al., 1990; Wiencek et al., 1990).

\section{Materials and methods}

\subsection{B. subtilis strains and growth conditions}

Nine B. subtilis strains were used: ATCC 7058 , ATCC 12432, ATCC 12695, ATCC 15129, ATCC 15476, ATCC 15561, ATCC 15811, B 213 and S 499. The ATCC strains originate from American Type Culture Collection. The strain B 213 was isolated from strawberry by the Centre Wallon de Biologie Industrielle, Gembloux. The strain S 499 was collected in the region of Ituri, Congo (formerly Zaire) (Delcambe, 1965) and supplied by L. Delcambe.
Overnight precultures were used for inoculation. The cultures of vegetative cells were performed in 868 medium (10 $\mathrm{g}^{-1}$ peptone, $10 \mathrm{~g}^{-1}$ yeast extract and $20 \mathrm{~g}^{-1}$ glucose in distilled water) at $30^{\circ} \mathrm{C}$ with shaking $(130 \mathrm{rpm})$. Cells were harvested after $48 \mathrm{~h}$ i.e. in the stationary growth phase. They were washed three times by resuspension in demineralized water and centrifugation for $10 \mathrm{~min}$ at $9630 \times g$ and $25^{\circ} \mathrm{C}$ (centrifuge Beckman J2-21, rotor model JA-14). The absence of spores was checked by diluting $1 \mathrm{ml}$ of each bacterial suspension in $9 \mathrm{ml}$ of physiological liquid ( $1 \mathrm{~g}^{-1}$ peptone, $5 \mathrm{~g} \mathrm{l}^{-1}$ $\mathrm{NaCl}$ and $2 \mathrm{ml}^{-1}$ Tween 80), heating for $10 \mathrm{~min}$ at $80^{\circ} \mathrm{C}$, and spreading on agar plates $\left(10 \mathrm{~g}^{-1}\right.$ agar, 10 $\mathrm{g}^{-1}$ peptone, $10 \mathrm{~g}^{-1}$ yeast extract and $20 \mathrm{~g} \mathrm{l}^{-1}$ glucose).

In order to obtain spores, cultures (mode $\mathrm{Sp}$ ) were performed as described above, except that the glucose concentration was twice lower and that the cultures lasted 7 days. The vegetative cells were killed by heating for $10 \mathrm{~min}$ at $80^{\circ} \mathrm{C}$ as described by Rönner et al. (1990) and Garry et al. (1998). The cells were then harvested by centrifugation $(9630 \times g$ for $10 \mathrm{~min}$ and $25^{\circ} \mathrm{C}$ ) and washed three times with demineralized water. The suspension thus obtained was stored at $4^{\circ} \mathrm{C}$ until use.

The proportion of spores at the end of the $\mathrm{Sp}$ cultures was determined by performing a count on agar plates, before (total count) and after (spores only) heating the cell suspension for $10 \mathrm{~min}$ at $80^{\circ} \mathrm{C}$. This determination was performed on at least two separate cultures, using five dilutions $\left(10^{3}, 10^{4}, 10^{5}\right.$, $10^{6}$ and $\left.10^{7}\right)$ and making three countings for each dilution.

\subsection{Contact angle measurements}

Hydrophobicity of $B$. subtilis cells was determined by water contact angle measurements on bacterial lawns deposited on membrane filters as described by Busscher et al. (1984). Bacteria suspended in demineralized water were filtered on a cellulose acetate membrane filter (pore diameter 0.45 $\mu \mathrm{m}$; Gelman). The filters carrying the bacterial lawns (more than $1 \times 10^{8}$ cells $\mathrm{mm}^{-2}$ ) were then placed in a Petri dish on $1 \%$ (weight/volume) agar layer containing $10 \%$ (volume/volume) glycerol, and stored for $2 \mathrm{~h}$ to homogenize the moisture content. 
Table 1

Bacterial density and percentage of sporulation $(\%)$ of Bacillus subtilis strains obtained with the Sp culture mode

\begin{tabular}{lrrl}
\hline Strains & \multicolumn{2}{l}{$\begin{array}{l}\text { Bacterial density } \\
\left(10^{8} \text { cells ml }^{-1}\right)\end{array}$} & $\begin{array}{l}\text { Percentage of } \\
\text { sporulation }(\%)\end{array}$ \\
\cline { 2 - 3 } & \multicolumn{1}{c}{ Total } & \multicolumn{1}{c}{ Spores } \\
\hline ATCC 7058 & $7.3 \pm 0.5$ & $6.9 \pm 0.4$ & $94 \pm 1$ \\
ATCC 12432 & $0.6 \pm 0.2$ & $0.6 \pm 0.1$ & $89 \pm 4$ \\
ATCC 12695 & $15.7 \pm 3.1$ & $4.2 \pm 0.7$ & $26 \pm 5$ \\
ATCC 15129 & $15.2 \pm 2.6$ & $13.8 \pm 3.5$ & $91 \pm 1$ \\
ATCC 15476 & $2.8 \pm 1.3$ & $2.2 \pm 0.7$ & $79 \pm 3$ \\
ATCC 15561 & $2.7 \pm 0.4$ & $1.7 \pm 0.1$ & $63 \pm 7$ \\
ATCC 15811 & $12.3 \pm 3.1$ & $10.5 \pm 1.5$ & $85 \pm 5$ \\
B 213 & $5.2 \pm 1.1$ & $0.4 \pm 0.2$ & $8 \pm 4$ \\
S 499 & $3.0 \pm 0.2$ & $0.01 \pm 0.001$ & $1 \pm 1$ \\
\hline
\end{tabular}

The filters were dried in the air for $60 \mathrm{~min}$ in order to obtain relatively stable contact angles. At least three filters, each from a different culture, were used for every bacterial strain and physiological state. Water droplets $(10 \mu 1)$ were applied at 10 different places at $25^{\circ} \mathrm{C}$ for every filter. The results presented are thus the means of 30 measurements. Water contact angles were measured with an Erma Contact Angle Meter G1 (Krüss, Germany).

\subsection{Hydrophobic interaction chromatography (HIC)}

The test consists in measuring the amount of cells retained by a hydrophobic gel (Clark et al., 1985; Mozes and Rouxhet, 1987). Washed cells were suspended in $10 \mathrm{mM}$ of phosphate buffered saline solution (PBS) containing $0.87 \mathrm{~g} \mathrm{l}^{-1} \mathrm{~K}_{2} \mathrm{HPO}_{4}, 0.68 \mathrm{~g}$ $1^{-1} \mathrm{KH}_{2} \mathrm{PO}_{4}$ and $8.77 \mathrm{~g}^{-1} \mathrm{NaCl}(\mathrm{pH} 6.8)$ (Merck, Darmstadt, Germany). Hydrophobic interaction chromatography was performed in small columns, prepared from Pasteur pipettes $(\phi=5 \mathrm{~mm})$ containing $0.6 \mathrm{ml}$ of phenyl Sepharose CL-4B or Sepharose CL-4B (Pharmacia, Sweden), which served as a non-hydrophobic control. Gels were equilibrated with $3 \mathrm{ml}$ of the PBS solution. $0.1 \mathrm{ml}$ of cell suspensions $\left(1 \times 10^{8}\right.$ cells $\left.\mathrm{ml}^{-1}\right)$ was applied to the gel and eluted with $3 \mathrm{ml}$ of PBS solution. The absorbance at $600 \mathrm{~nm}$ was measured on the initial suspension and on the eluate, providing a percentage of retention. The hydrophobicity was evaluated by the difference of the retention percentages by phenyl Sepharose CL-4B and Sepharose CL-4B (close to 1\%). At least two different cultures were tested for every strain and physiological state, and four measurements were done per culture $(n=8)$.

\subsection{Bacterial adhesion to hydrocarbon (BATH)}

It has been shown that the surfaces of aliphatic hydrocarbons used in BATH method ( $n$-octane and $n$-hexadecane), in contact with various aqueous solutions at $\mathrm{pH} 7$, including PBS, were more negatively charged compared to aromatic hydrocarbons (toluene and p-xylene) (Busscher et al., 1995). Therefore, toluene was used in the present study. The experiments were carried out as described by Rosenberg et al. (1980). Toluene was obtained from Merck (Darmstadt, Germany) in highest purity grade (Mozes and Rouxhet, 1987). The washed cells were suspended at a density of $1 \times 10^{8}$ cells $\mathrm{ml}^{-1}$ in PBS. One hundred fifty microliters of toluene was added to $3 \mathrm{ml}$ of bacterial suspension; the mixture was vortexed for $10 \mathrm{~s}$, allowed to settle for $10 \mathrm{~min}$ and the absorbance of the aqueous phase was measured at $600 \mathrm{~nm}$ (van der Mei et al., 1995). It must be noted that an emulsion (eye-visible transparent droplets) was produced at the separation between bulk water and toluene phases. The percentage of

Table 2

Evaluation of the surface hydrophobicity of Bacillus subtilis vegetative cells $(\mathrm{Vg})$ and cell obtained by the culture mode Sp: water contact angle measurement (CAM), hydrophobic interaction chromatography (HIC), and bacterial adhesion to hydrocarbon (BATH)

\begin{tabular}{|c|c|c|c|c|c|c|}
\hline \multirow[t]{3}{*}{ Strains } & \multicolumn{6}{|c|}{ Bacterial surface hydrophobicity } \\
\hline & \multicolumn{2}{|c|}{$\mathrm{CAM}^{\mathrm{a}}$} & \multicolumn{2}{|l|}{$\mathrm{HIC}^{b}$} & \multicolumn{2}{|c|}{$\mathrm{BATH}^{\mathrm{c}}$} \\
\hline & $\mathrm{Vg}$ & $\mathrm{Sp}$ & $\mathrm{Vg}$ & $\mathrm{Sp}$ & $\mathrm{Vg}$ & $\mathrm{Sp}$ \\
\hline ATCC 7058 & $31 \pm 2$ & $59 \pm 3$ & $62 \pm 2$ & $57 \pm 4$ & $42 \pm 4$ & $48 \pm 3$ \\
\hline ATCC 12432 & $31 \pm 1$ & $55 \pm 3$ & $16 \pm 3$ & $35 \pm 3$ & $20 \pm 3$ & $25 \pm 4$ \\
\hline ATCC 12695 & $34 \pm 1$ & $33 \pm 2$ & $48 \pm 3$ & $40 \pm 2$ & $36 \pm 3$ & $49 \pm 3$ \\
\hline ATCC 15129 & $32 \pm 1$ & $42 \pm 1$ & $4 \pm 2$ & $50 \pm 2$ & $6 \pm 3$ & $24 \pm 2$ \\
\hline ATCC 15476 & $20 \pm 2$ & $44 \pm 1$ & $12 \pm 3$ & $35 \pm 3$ & $17 \pm 4$ & $21 \pm 3$ \\
\hline ATCC 15561 & $28 \pm 2$ & $52 \pm 2$ & $8 \pm 2$ & $61 \pm 3$ & $26 \pm 3$ & $39 \pm 3$ \\
\hline ATCC 15811 & $47 \pm 2$ & $49 \pm 2$ & $53 \pm 4$ & $58 \pm 4$ & $66 \pm 2$ & $68 \pm 3$ \\
\hline B 213 & $27 \pm 2$ & $48 \pm 3$ & $9 \pm 3$ & $7 \pm 3$ & $7 \pm 3$ & $19 \pm 4$ \\
\hline S 499 & $34 \pm 2$ & $46 \pm 2$ & $11 \pm 3$ & $14 \pm 3$ & $15 \pm 5$ & $17 \pm 3$ \\
\hline
\end{tabular}

${ }^{\mathrm{a}}$ Values are in degree \pm the standard deviation $(n=30)$.

${ }^{b}$ Values are in percentage of cells retained by the phenyl Sepharose \pm the standard deviation $(n=8)$.

${ }^{c}$ Values are in percentage of cells removed from water \pm the standard deviation $(n=8)$. 
cells removed from water was determined by optical density measurements. At least two different cultures were tested for every strain and physiological state, and four measurements were done for each culture $(n=8)$.

\subsection{Zeta potential measurements}

The washed cells were suspended in $10 \mathrm{mM}$ $\mathrm{NaCl}$. Aliquots were added in solution of defined $\mathrm{pH}$

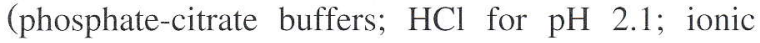
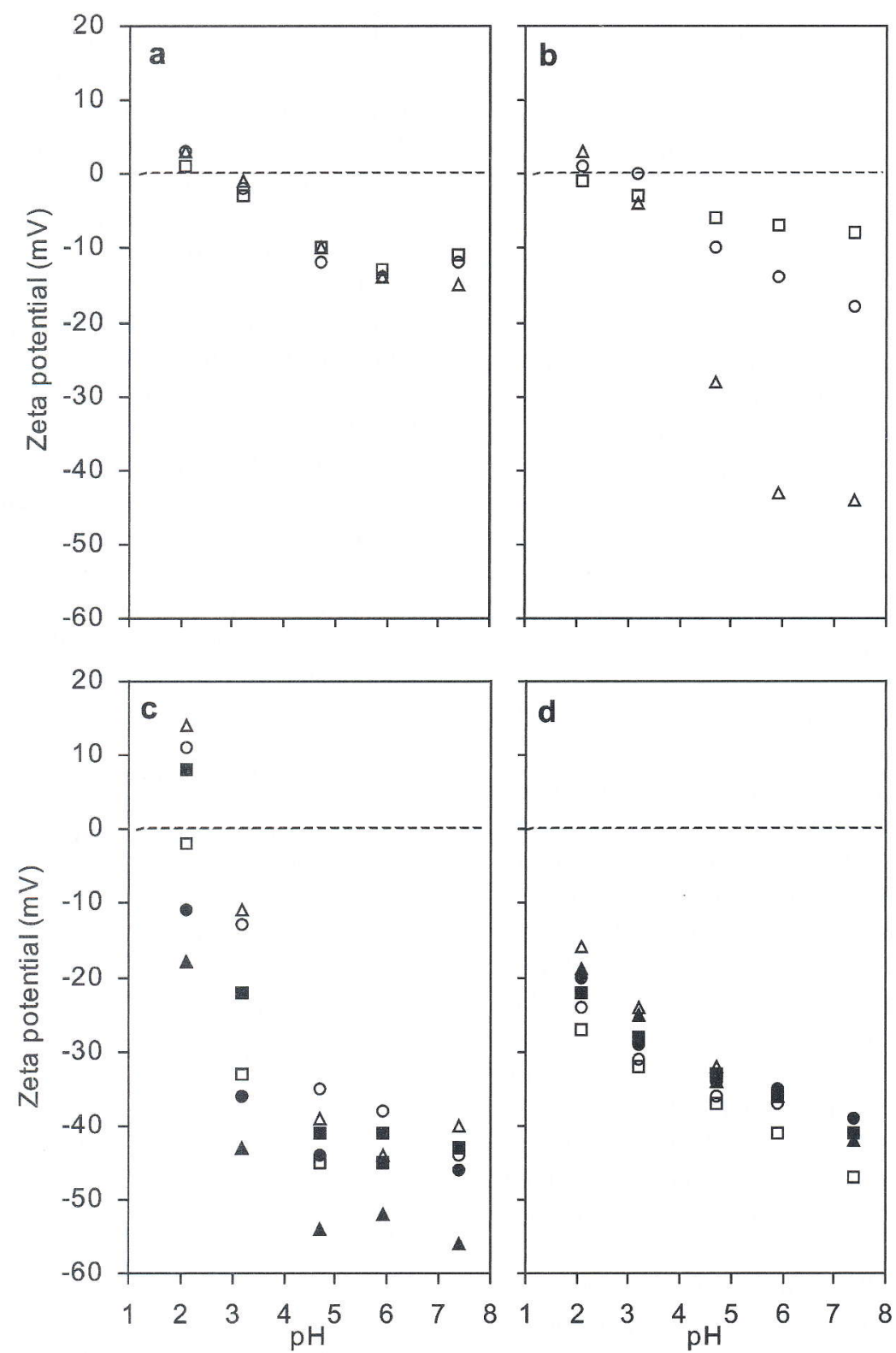

Fig. 1. Zeta potential of B. subtilis measured as function of $\mathrm{pH}$ (phosphate-citrate buffers; $\mathrm{HCl}$ for $\mathrm{pH} 2.1$; ionic strength $2 \mathrm{mM}$ ) (standard deviation of $3 \mathrm{mV}$ ). Strains showing a weak zeta potential at low pH: (a) vegetative cells; (b) spores; O, ATCC 7058; $\triangle$, ATCC 12432; $\square$, ATCC 15811. Strains showing a strongly negative zeta potential at low pH: (c) vegetative cells; (d) cells cultured by mode Sp; O, ATCC 12695; ATCC 15129; $\triangle$, ATCC 15476; «, ATCC 15561; $\square$, B 213; $\mathbf{- 1}$, S 499. 
strength $2 \mathrm{mM}$ ) to reach a density of $1 \times 10^{8}$ cells $\mathrm{ml}^{-1}$. Zeta potentials were measured at $25^{\circ} \mathrm{C}$ with a Malvern Zeta Sizer 3 (Malvern Instruments, England). At least three different cultures were tested for every strain and physiological state, and two measurements were performed for each culture $(n=6)$.

\section{Results}

The bacterial density obtained with the Sp culture mode and the percentage of sporulation of Bacillus subtilis varied according to the strain (Table 1). For certain strains (ATCC 7058, ATCC 12432, ATCC 15129, ATCC 15476, ATCC 15811), the suspension obtained according to mode $\mathrm{Sp}$ consisted essentially of spores (more that about 80\%). Two strains, B 213 and S 499, showed a weak degree of sporulation; the material collected after heating and washing could thus consist of dead cells. ATCC 12695 and ATCC 15561 give an intermediate situation. The presence of a high proportion of dead cells in the suspensions of certain strains prepared according to mode $\mathrm{Sp}$ could affect the microbiological relevance of the data. However, the latter will still be considered in the comparison of surface characterization methods, with a clear indentification, in order to examine
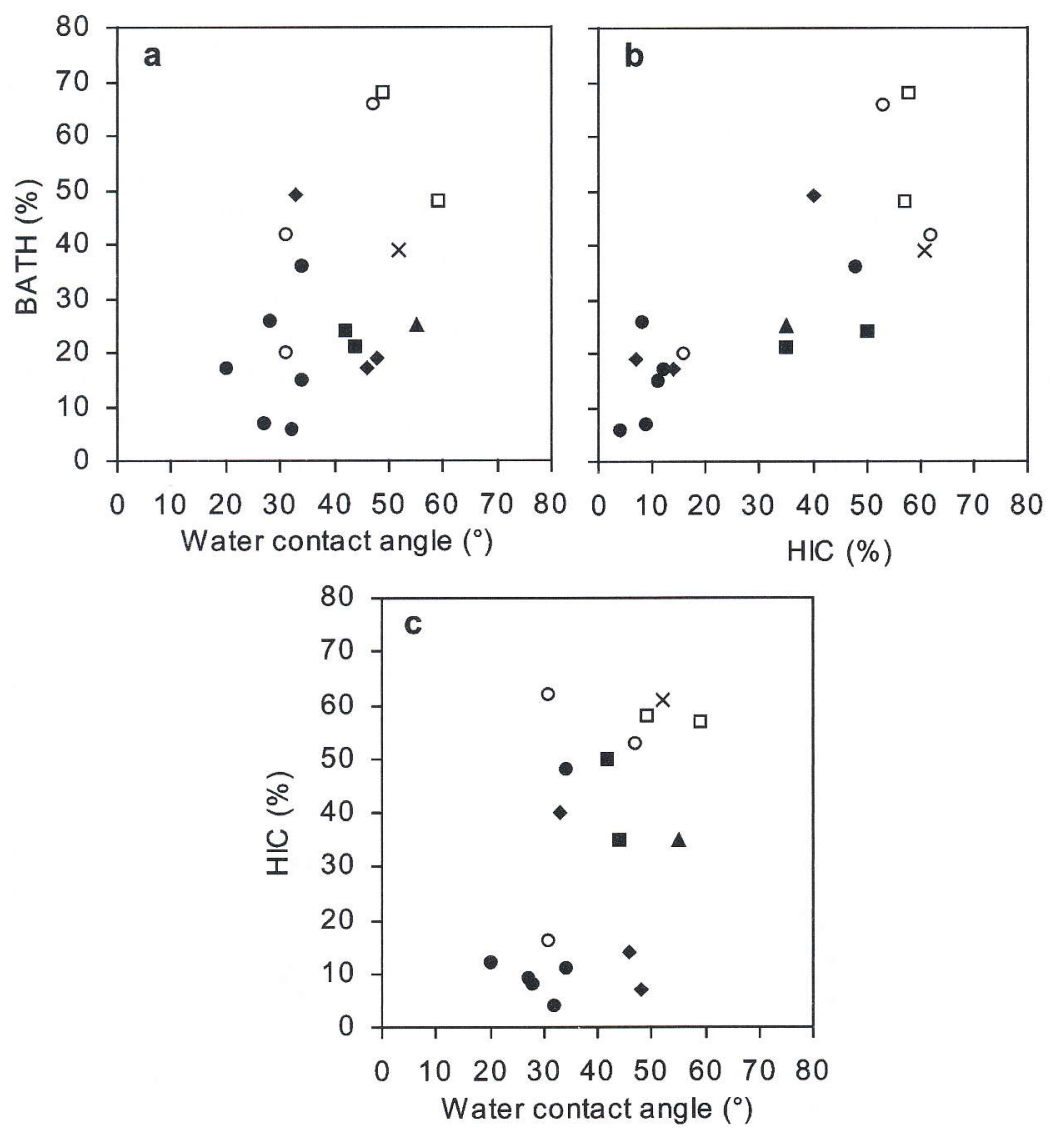

Fig. 2. Cross correlations between bacterial adhesion to hydrocarbon (BATH), hydrophobic interaction chromatography (HIC) and water contact angle for Bacillus subtilis: $\bigcirc$, vegetative cells giving a low zeta potential at $\mathrm{pH} 6$; $\square$, spores giving a zeta potential at pH 6 ; vegetative cells giving a high zeta potential at $\mathrm{pH} 6$; $\mathbf{0}$, spores giving a high zeta potential at $\mathrm{pH}$. Other symbols refer to cells cultured by mode Sp and showing a high zeta potential at pH 6: ^, ATCC 12432 (low zeta potential at pH 3); $\times$, ATCC 15561 (63\% spores); $\bullet$ percent sporulation not larger than $26 \%$. 
whether dead cells deviate systematically with respect to vegetative cells and spores.

Table 2 shows $B$. subtilis hydrophobicity assessed by water contact angle measurements, hydrophobic interaction chromatography (HIC) and bacterial adhesion to hydrocarbon (BATH). These results show that the hydrophobicity varied according to the strain and to the physiological state.

The zeta potential of $B$. subtilis cells was measured as a function of $\mathrm{pH}$. For each strain and physiological state, the zeta potential curves versus $\mathrm{pH}$ were determined on at least three independent cultures, and a good reproducibility was obtained (standard deviation of $3 \mathrm{mV}$ ). The results, presented in Fig. 1, varied greatly and showed two clear-cut behaviors. The first behavior (spores and vegetative cells of ATCC 7058 and ATCC 15811, vegetative cells of ATCC 12432) was characterized by a weak zeta potential (Fig. 1a and b). The other cells presented a strongly negative zeta potential above $\mathrm{pH}$ 3.2 (Fig. 1b-d). Within this category the vegetative cells (Fig. 1c) presented a sharp variation of the zeta potential between $\mathrm{pH} 2$ and 4.7 and little variation above $\mathrm{pH}$ 4.7. When these strains were cultured according to Sp mode (Fig. 1d), the zeta potential varied progressively from $\mathrm{pH} 2$ to $\mathrm{pH} 7.5$ and the isoelectric points $(\mathrm{pHi})$ of all of them were lower compared to the vegetative cells (Fig. 1c). No significant difference was found between the strains in the form of essentially dead cells (B 213 and S 499), of essentially spores (ATCC 15129 and ATCC 15476), or of a mixture of both (ATCC 12695 and ATCC 15561).

\section{Discussion}

It appears from Fig. 1 that the zeta potential depends on the strain but does not vary systematically according to the state. It has been suggested that physiologically active $B$. subtilis may be less negatively charged than inactive cells, due to a lower $\mathrm{pH}$ near the surface, compared to the surrounding medium. (Kosh, 1986; Kemper et al., 1993). This is not observed here, except possibly for ATCC 12432.

The hydrophobicity of $B$. subtilis varies greatly according to the method used, the strain and the physiological state. Fig. 2 presents cross correlations between the data obtained with the three methods of hydrophobicity evaluation. It shows that the results of BATH and HIC are better correlated with each other than with the water contact angle: the correlation coefficient between BATH and HIC is 0.80 , while the correlation coefficient with the water contact angle is 0.50 for HIC and 0.43 for BATH. The correlation coefficients are $0.81,0.60$ and 0.52 , respectively, if the four samples containing a high proportion of dead cells are not taken into considera-
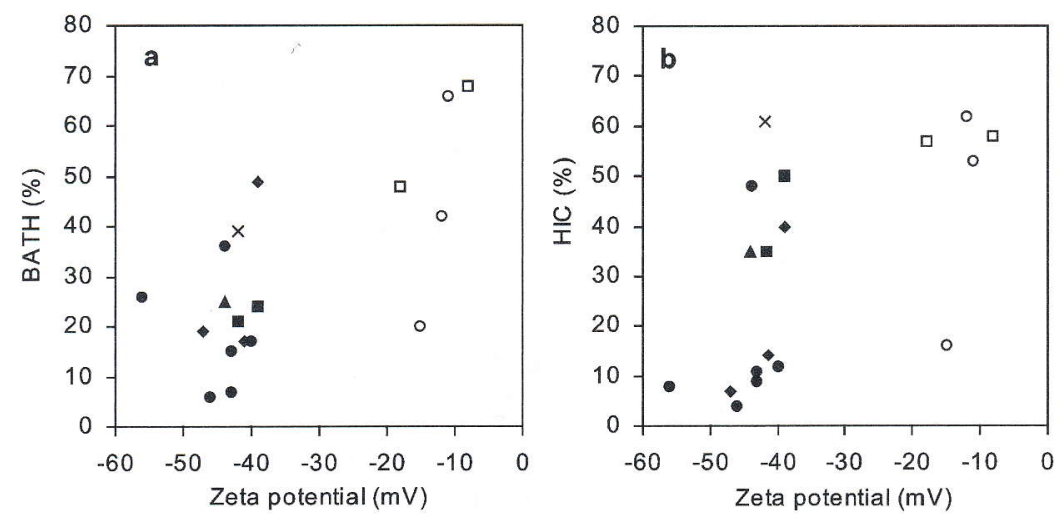

Fig. 3. Correlations between bacterial adhesion to hydrocarbon (a), hydrophobic interaction chromatography (b) and zeta potential of $B$. subtilis measured at $\mathrm{pH} 7.4$ : $\bigcirc$, vegetative cells giving a low zeta potential at $\mathrm{pH} 6$; $\square$, spores giving a low zeta potential at $\mathrm{pH}$ 6; vegetative cells giving a high zeta potential at $\mathrm{pH}$; ; spores giving a high zeta potential at $\mathrm{pH}$. Other symbols refer to cells cultured by mode Sp and showing a high zeta potential at pH 6: A, ATCC 12432 (low zeta potential at pH 3); ×, ATCC 15561 (63\% spores); percent sporulation not larger than $26 \%$. 
tion. Moreover, the contact angle tends to be higher for spores compared to vegetative cells, while no systematic difference appears with BATH and HIC.

Fig. 3 presents plots of BATH (a) and HIC (b) as a function of the zeta potential at $\mathrm{pH}$ 7.4. Correlation coefficients are 0.68 and 0.60 , respectively. They become 0.81 and 0.60 if the four samples containing a high proportion of dead cells are not taken into account. In contrast, the corresponding correlation coefficients between the water contact angle and the zeta potential are 0.24 and 0.16 . The correlation coefficients thus vary according to the sequence $\mathrm{BATH} / \mathrm{HIC}>\mathrm{BATH}$ or $\mathrm{HIC} /$ zeta potential $>$ $\mathrm{BATH}$ or $\mathrm{HIC} /$ contact angle $>$ contact angle/zeta potential. This reveals that the outcomes of BATH and HIC are both influenced by surface electrical properties, in contrast, with the water contact angle. This conclusion remains valid whether samples with a high proportion of dead cells are considered or not in the comparison of data.

It has been pointed out that all hydrocarbons currently employed in BATH method give a negatively charged interface with water and most buffers, so that BATH is sensitive to both electrostatic and hydrophobic interactions (Geertsema-Doornbusch et al., 1993; Busscher et al., 1995; van der Mei et al., 1995). By examining the influence of $\mathrm{pH}$ and ionic strength on HIC data, Mozes and Rouxhet (1987) concluded that the electrostatic repulsions prevent cell retention by phenyl Sepharose. Wiencek et al. (1990) also reported that a high ionic strength was necessary to overcome the electrostatic repulsion between spores and phenyl Sepharose.

The results presented here confirm on a statistical basis that both BATH and HIC are affected by electrostatic interactions. This is not the case of the water contact angle, which reveals surface hydrophobicity or polarity without interference of long range electrostatic interactions.

\section{Conclusion}

A comparison of different strains and states of $B$. subtilis has shown that BATH and HIC are influenced by electrostatic interactions. Thus, the water contact angle provides a better evaluation of cell surface hydrophobicity.

\section{Acknowledgements}

This work received financial support from the European Union (Bio 4-CT 950176), National Foundation for Scientific Research (FNRS) and Federal Office for Scientific, Technical and Cultural Affairs (Interuniversity Poles of Attraction Programme).

\section{References}

Absolom, D.R., Lamberti, F.V., Policova, Z., Zingg, W., van Oss, C.J., Neu, A.W., 1983. Surface thermodynamics of bacterial adhesion. Appl. Environ. Microbiol. 46, 90-97.

Ahimou, F., Jacques, Ph., Deleu, M., 2000. Surfactin and iturin A effects on Bacillus subtilis surface hydrophobicity. Enzyme Microbial. Technol. 27, 749-754.

Asaka, O., Shoda, M., 1996. Biocontrol of Rhizoctonia solani damping-off of tomato with Bacillus subtilis RB14. Appl. Environ. Microbiol. 62, 4081-4085.

Busscher, H.J., Weerkamp, A.H., van der Mei, H.C., van Pelt, A.W.J., De Jong, H.P., Arends, J., 1984. Measurement of the surface free energy of bacterial cell surfaces and its relevance for adhesion. Appl. Environ. Microbiol. 48, 980-983.

Busscher, H.J., van de Belt-Gritter, B., van der Mei, H.C., 1995. Implications of microbial adhesion to hydrocarbons for evaluating cell surface hydrophobicity. 1. Zeta potentials of hydrocarbon droplets. Colloids Surf., B 5, 111-116.

Clark, W.B., Lane, M.D., Beem, E., Bragg, S.L., Wheeler, T.T., 1985. Relative hydrophobicities of Actinomyces viscosus and Actinomyces naeslundii strains and their adsorption to salivatreated hydroxyapatite. Infect. Immun. 47, 730-736.

Delcambe, L., 1965. L'iturine. Préparation, purification et poids moléculaire. Bull. Soc. Chim. Bel. 74, 315-328.

Dewez, J.L., Berger, V., Schneider, Y.J., Rouxhet, P.G., 1997. Influence of substrate hydrophobicity on the adsorption of collagen in the presence of pluronic F68, albumin, or calf serum. J. Colloid Interface Sci. 191, 1-10.

Dillon, J.K., Fuerst, J.A., Hayward, A.C., Davis, G.H.G., 1986. A comparison of five methods for assaying bacterial hydrophobicity. J. Microbiol. Methods 6, 13-19.

Doyle, R.J., 1984. Hydrophobic characteristics of Bacillus spores. Curr. Microbial. 10, 329-332.

Garry, P., Andersen, T., Vendeuvre, J.L., Bellon-Fontaine, M.N., 1995. Influence de la rugosité de surfaces en polyuréthane sur l'adhésion de Bacillus subtilis et de Bacillus cereus. In: Bellon-Fontaine, M.-N., Fourniat, J. (Eds.), Adhésion des Micro-organismes Aux Surfaces. Lavoisier, Paris, pp. 21-30.

Garry, P., Vendeuvre, J.L., Bellon-Fontaine, M.N., 1998. Surface properties and adhesion of Bacillus cereus and Bacillus subtilis to polyurethane- influence of growth temperature. J. Dispersion Sci. Technol. 19, 1175-1197.

Geertsema-Doornbusch, G.I., van der Mei, H.C., Busscher, H.J., 1993. Microbial cell surface hydrophobicity. The involvement 
of electrostatic interactions in microbial adhesion to hydrocarbons (MATH). J. Microbiol. Methods 18, 61-68.

Husmark, U., Rönner, U., 1990. Forces involved in adhesion of Bacillus cereus spores to solid surfaces under different environmental conditions. J. Appl. Bacteriol. 69, 557-562.

Kemper, M.A., Urrutia, M.M., Beveridge, T.J., Koch, A.L., Doyle, R.J., 1993. Proton motive force may regulate cell wall-associated enzymes of Bacillus subtilis. J. Bacteriol. 175, 56905696.

Kosh, A.L., 1986. The $\mathrm{pH}$ in the neighborhood of membranes generating a proton motive force. J. Theor. Biol. 120, 73-84

Koshikawa, T., Yamazaki, M., Yoshimi, M., Ogawa, S., Yamada, A., Watabe, K., Torii, M., 1989. Surface hydrophobicity of spores of Bacillus spp. J. Gen. Microbiol. 135, 2717-2722.

Mozes, N., Rouxhet, P.G., 1987. Methods for measuring hydrophobicity of microorganisms. J. Microbiol. Methods 6, $99-112$.

Paquot, M., Heuzé, V., Destain, J., Lepoivre, Ph., Tossut, P., Thonart, Ph., 1994. Surface hydrophobicity and electrical properties of Bacillus subtilis strains, potential phytopathogen antagonists in tomato crops. Colloids Surf., B 2, 451-456.

Razafindralambo, H., Deleu, M., Popineau, Y., Hbid, C., Jacques, P., Thonart, P., Paquot, M., 1998. Foaming properties of lipopeptides produced by Bacillus subtilis: effect of lipid and peptide structural attributes. J. Agric. Food Chem. 46, 911916.

Rönner, U., Husmark, U., Henriksson, A., 1990. Adhesion of Bacillus spores in relation to hydrophobicity. J. Appl. Bacteriol. 69, 550-556.

Rosenberg, M., Gutnick, D., Rosenberg, E., 1980. Adherence of bacteria to hydrocarbons: a simple method for measuring cell-surface hydrophobicity. FEMS Microbiol. Lett. 9, 29-33.

Rosenberg, E., Brown, D.R., Demain, A.L.. 1985. The influence of gramicidin $\mathrm{S}$ on hydrophobicity of germinating Bacillus brevis spores. Arch. Microbiol. 142, 51-54.

Stenström, A.T., 1989. Bacterial hydrophobicity, an overall parameter for the measurement of adhesion potential to soil particles. Appl. Environ. Microbiol. 55, 142-147.

Thimon, L., Peypoux, F., Maget-Dana, R., Michel, G., 1992. Surface-active properties of antifungal lipopeptides produced by Bacillus subtilis. J. Am. Oil Chem. Soc. 69, 92-93.

Van der Mei, H.C., Weerkamp, A.H., Busscher, H.J., 1987. A comparison of various methods to determine hydrophobic properties of streptococcal cell surfaces. J. Microbiol. Methods 6, 277-287.

Van der Mei, H.C., van de Belt-Gritter, B., Busscher, H.J., 1995. Implications of microbial adhesion to hydrocarbons for evaluating cell surface hydrophobicity: 2. Adhesion mechanisms. Colloids Surf., B 5, 117-126.

Van Loosdrecht, M.C.M., Lyklema, J., Norde, W., Schraa, G., Zehnder, A.J.B., 1987a. The role of bacterial cell wall hydrophobicity in adhesion. Appl. Environ. Microbiol. 53, 1893-1897.

Van Loosdrecht, M.C.M., Lyklema, J., Norde, W., Schraa, G., Zehnder, A.J.B., 1987b. Electrophoretic mobility and hydrophobicity as a measure to predict the initial steps of bacterial adhesion. Appl. Environ. Microbiol. 53, 1898-1901.

Wiencek, K.M., Klapes, N.A., Foegeding, P.M., 1990. Hydrophobicity of Bacillus and Clostridium spores. Appl. Environ. Microbiol. 56, 2600-2605. 